\title{
Old tiger man: a case of sarcoid myopathy
}

\author{
João Ferreira Fonseca, ${ }^{1,2}$ Flávio Costa ${ }^{3}$ Manuel Teixeira Veríssimo, 1,2 \\ Armando Carvalho ${ }^{1,2}$
}

${ }^{1}$ Department of Internal Medicine, Coimbra Hospital and Universitary Centre, Coimbra, Portugal

${ }^{2}$ Faculty of Medicine, University of Coimbra, Coimbra, Portugal ${ }^{3}$ Rheumatology Department, Coimbra Hospital and Universitary Centre, Coimbra, Portugal

\section{Correspondence to} Dr João Ferreira Fonseca, mudbuda@gmail.com

Accepted 28 July 2017

\section{DESCRIPTION}

A 76-year-old man presented with asthenia and proximal muscle weakness during the past 6 months. A general physical examination proved to be unremarkable. Blood tests showed hypercalcaemia (ionised calcium $1.52 \mathrm{mmol} / \mathrm{L}$ ) and normal creatine phosphokinase (CPK). Additional studies findings included: suppressed parathyroid hormone level $(<2.5 \mathrm{pg} / \mathrm{mL})$, low $1,25(\mathrm{OH})_{2}$ vitamin D $(14 \mathrm{ng} / \mathrm{mL})$ and elevated serum angiotensin-converting enzyme (107 IU/L). Cell blood count, renal function, $\mathrm{C}$ reactive protein, erythrocyte sedimentation rate and urinary calcium were normal. A fluorodeoxyglucose positron emission tomography (FDG-PET) scan was ordered demonstrating enlarged hilar, mediastinal and right supraclavicular lymph nodes (figure 1A) and diffuse linear abnormal hypercaptation of the musculature (figures 1B and 2). Although the electromyogram (EMG) has not shown changes, a biopsy of the gastrocnemius muscle presented well-defined non-necrotising granulomas, suggesting sarcoid myopathy. Exclusion of other granulomatous diseases enabled the definitive diagnosis. The patient was successfully treated with prednisolone.

\section{DISCUSSION}

Sarcoid myopathy is a disorder of unknown cause. It is characterised by non-caseating granulomas. Symptomatic involvement occurs in $0.5 \%-5 \%$ and is rarely inaugural or isolated. Three different types

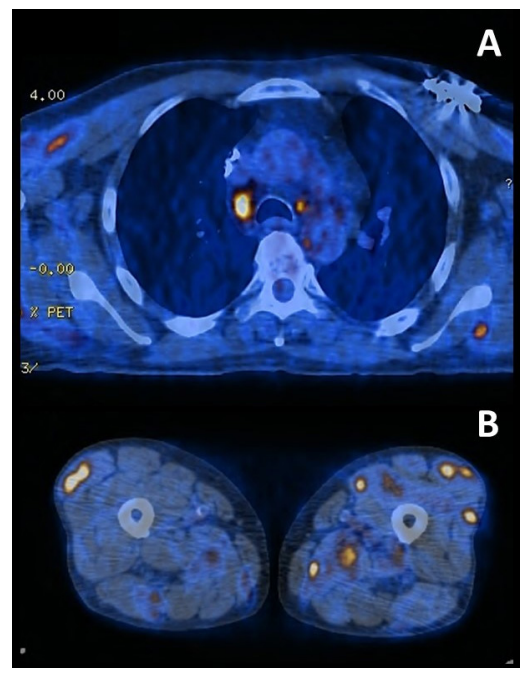

To cite: Fonseca JF, Costa F, Veríssimo MT, et al. BMJ Case Rep Published Online First: [please include Day Month Year]. doi:10.1136/bcr-2017 220177
CrossMark

Figure 1 F-18 FDG PET/CT findings. Increased uptake was noted in hilar and mediastinal lymph nodes (A), transaxial images. and nodular hypercaptation was seen in both legs (B) in

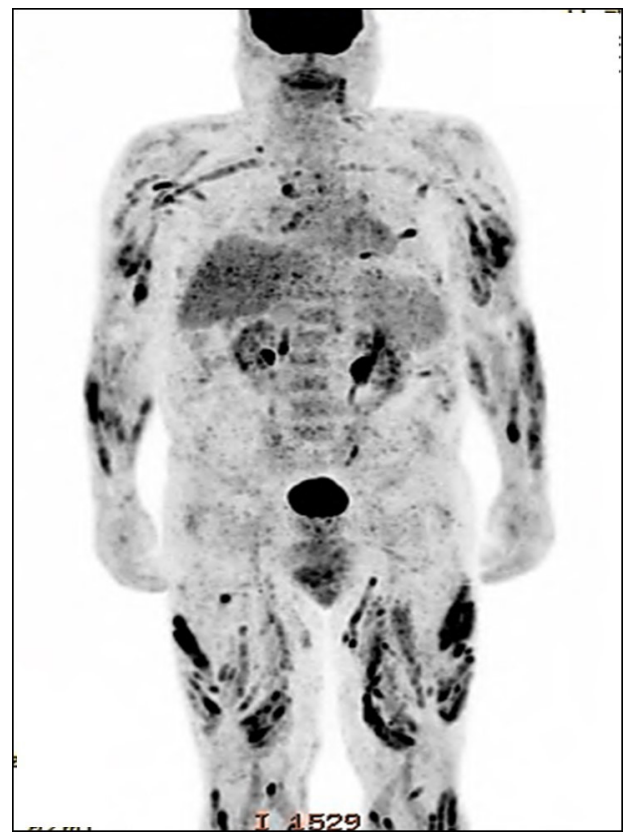

Figure 2 F-18 FDG PET/CT findings. Maximum intensity projection mode shows the characteristic linear 'tiger man' uptake pattern of muscular sarcoidosis in upper and lower limbs.

were defined: chronic myopathy, palpable nodules and acute myositis. ${ }^{1}$

This case seems to fit into chronic myopathy, which is the most common symptomatic form (85\%). In this condition, the patient experiences a slowly progressive proximal symmetrical weakness. A favourable clinical response with corticosteroids is usually observed. ${ }^{1}$

The FDG-PET muscular uptake pattern observed in our patient, known as 'tiger man' sign, was first

\section{Learning points}

- The elevation of serum angiotensin-converting enzyme may be an important clue to the diagnosis of sarcoidosis in the context of hypercalcaemia.

- Diagnostic workup of sarcoid myopathy includes muscle enzymes, electromyogram (EMG) and muscle biopsy. However, normal CPK and EMG do not exclude muscular involvement in sarcoidosis. ${ }^{1}$

- FDG-PET has a major role to access sarcoidosis activity and guide a biopsy. A characteristic multiple linear 'tiger man' uptake pattern can be found in muscular sarcoidosis. ${ }^{23}$ 
described in 2012 and is rarely reported. ${ }^{2}$ This particular finding was crucial to achieving the diagnosis, considering that EMG and $\mathrm{CPK}$ were normal.

Contributors JFF and FC wrote the manuscript and performed a review of the literature. MTV and AC contributed to critical revision of the article and approved the final version.

Competing interests None declared.

Patient consent Obtained.

Provenance and peer review Not commissioned; externally peer reviewed. (c) BMJ Publishing Group Ltd (unless otherwise stated in the text of the article) 2017. All rights reserved. No commercial use is permitted unless otherwise expressly granted.

\section{REFERENCES}

1 Fayad F, Lioté F, Berenbaum F, et al. Muscle involvement in sarcoidosis: a retrospective and followup studies. J Rheumatol 2006;33:98-103.

2 Wieërs G, Lhommel R, Lecouvet F, et al. A tiger man. Lancet 2012;380:1859.

3 Soussan M, Augier A, Brillet PY, et al. Functional imaging in extrapulmonary sarcoidosis: FDG-PET/CT and MR features. Clin Nucl Med 2014;39:e146-59.

Copyright 2017 BMJ Publishing Group. All rights reserved. For permission to reuse any of this content visit http://group.bmj.com/group/rights-licensing/permissions.

BMJ Case Report Fellows may re-use this article for personal use and teaching without any further permission.

Become a Fellow of BMJ Case Reports today and you can:

- Submit as many cases as you like

- Enjoy fast sympathetic peer review and rapid publication of accepted articles

- Access all the published articles

Re-use any of the published material for personal use and teaching without further permission

For information on Institutional Fellowships contact consortiasales@bmjgroup.com

Visit casereports.bmj.com for more articles like this and to become a Fellow 